\title{
Monitoring the Indoor Air Quality and Microclimate for Improving Passenger Health and Comfort Level in Bucharest Subway Platforms
}

\begin{abstract}
GABRIEL TUDOR, MARIUS DANIEL BONTOS*, OANA MIHAELA VASILIU (CONSTANTINESCU), CLAUDIA GEORGIANA VASILIU
University Politehnica of Bucharest, Faculty of Power Engineering, 313 Spl. Independentei, 060042, Bucharest, Romania

This paper presents the results of the air quality by the content of $\mathrm{CO}_{2^{\prime}} \mathrm{CO}, P M_{25^{\prime}} P M_{10}$ and the microclimate (temperature and relative humidity) monitoring campaign, in Bucharest underground transport network. The monitoring was performed using both manual and automatic data acquisition systems. All the acquired data were stored in a specific database system used for fast reporting and alarming. GIS software was used to precisely locate the exterior air intakes for selected stations in order to know the quality of the exterior air circulated through them and for finding the best position for new ones. The research was conducted on different station platforms, belonging to the same line, in the Bucharest subway system throughout a year (2015) in order to improve air quality and comfort level of subway stations. The obtained results will serve as basis for improving the air quality and comfort level in the new long subway lines designed and built now in Bucharest.
\end{abstract}

\section{Keywords: indoor microclimate, air quality monitoring, data acquisition systems, temperature-humidity index, Geographic Information System.}

Subway is vital for commuting in crowded cities and it is recognized that will become more and more important overtime.

According to recent studies [1-8], the comfort level, indoor air quality and security in underground transportation are a major environmental problem anywhere in the world. It is noticed that often the subway air has higher levels of air pollution than in trams or walking in the street. $[3,4]$ The related institutions and self-governing bodies must have continuous preoccupation to monitor, correct and make the right decisions in order to improve the subway environment current state.

In Bucharest (Romania) all subway lines and stations are exclusively underground and due to this feature the confined microclimate can accumulate different pollutants entering from the outside through ventilation systems in addition to those generated within the system by the frequency and speed of trains due to abrasion and wear of wheels, braking pads and rail tracks, caused during the motion of the trains, and subway stations and tunnels architecture.

Due to the particularities of Bucharest subway architecture, the heat and the substance flows may change several times within a year, cyclic regimes being controlled by reversing the ventilation on the winter-summer schedule. It is important to underline that subway stations make a heat transfer with the outside and vice versa.

This paper aims to conduct a study on indoor air quality in Bucharestunderground transport network. The subway netw ork consists of: 53 stations grouped in 4 lines, the total length of the network being $71.10 \mathrm{~km}$ of double track. In addition to the $71 \mathrm{~km}$ tunnel network, this subway has public and technical spaces, offices, laboratories, electrical substations, underground depots, draws, reserve lines, interstation areas for air tunnel evacuation when trains run, etc. All of these spaces greatly increase the total surface area of the underground transport netw ork [9].

With 106 trains and over 4500 employees the network carries up to 750000 daily passengers who often lead to excessive crowding and accumulation of various types of hazardous pollutants for human health. Even in these circumstances metro's interior environment must ensure thermal, optical, acoustic and bioclimatic comfort both for operating personnel and travelers.

For this case study, it is important to define the underground environment, which is unique due to the dynamics of external and internal factors which exertmajor influences on underground microclimate.

According to World Health Organization, environmental risk factors play a role in more than $80 \%$ of the diseases regularly reported and at global level nearly one quarter of all deaths and of the total disease burden can be attributed to the environment [10].

Indoor air quality is directly affected by the surrounding environment through the building materials used, the type and quality of ventilation, furniture and electrical appliances, cleaning and household products, occupant habits, the degree of maintenance of the building etc. $[2,5,11-14]$.

The subway environment must provide thermal, optical, acoustic and bioclimatic comfort for both operating staff and the passengers. The determining parameters for thermal comfort are air temperature and relative humidity. Thermal comfort can be achieved in the temperature range of $18-30^{\circ} \mathrm{C}$ and relative air humidity between $30-60 \%$ [15, $16]$.

The importance of indoor air temperature lies in its influence on the body's thermoregulation process. Air movement favors thermoregulation of organisms and has two parameters - speed and direction. The velocity of the air greatly influences the human body thermolysis and room ventilation. By acting on the sensitive skin receptors, air currents influence the central nervous system. In closed spaces air flows at speeds of $0.3-0.6 \mathrm{~m} / \mathrm{s}$ may cause unpleasant sensations.

Under the conditions of comfortable microclimate, the body's thermoregulatory processes are in a balanced state. It is manifested by a comfortable thermal state, optimal central nervous system functioning, increased physical and intellectual work capacity, increased resistance to harmful factors.

In case of microclimatic discomfort, the thermoregulation processes of the body are under the strain appearing unpleasant thermal sensation. Also, the functions of central nervous system deteriorate and the resistance to chemical and contagious agents decreases.

*email: bontos_marius@yahoo.com; Phone: 0723131388 
Uncomfortable microclimate may be the cause of acute or chronic illness [2, 5, 17].

In order to decrease the energy consumed to maintain the thermal comfort limit measures have been taken to reduce the air flow provided by the ventilation and also to seal all the sources of thermal energy. These measures have made important financial savings, but there have been problems with indoor air quality by increasing biological and chemical pollutant levels beyond normal limits. [18]

From the point of view of hygiene, air influences health through both its chemical composition and its physical properties $[2,5]$.

In terms of chemical composition, influence on the health derived from variations in normal component concentration and the presence of foreign compounds in the air. A normal chemical composition of the air indicates $20.95 \%$ oxygen. Small decreases in the concentration of up to $18 \%$ are tolerated without any disturbance by the human body. From a health point of view, the concentration of carbon dioxide oscillations, substances with a special role in the exchange of gases in the lungs, are important and can be considered as an indicator of air pollution when its value exceeds $0.07 \%[19,20]$.

\section{Experimental part}

For this case study the research was conducted on three station platforms in the Bucharest subway system throughout 2015 in order to improve air quality and comfort level of subway stations along to Line 1: Crangasi Subway

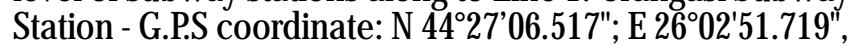
Gara de Nord 2 Subway Station - G.P.S coordinate: N $44^{\circ} 27^{\prime} 08.43^{\prime \prime} ;$ E 26 $05^{\prime} 10.68^{\prime \prime}$ and Eroilor Subway Station G.P.S coordinate: N 44²6'05.758"; E 2604'32.504".

GIS software was used to precisely locate the stations and the exterior air intakes in order to know the quality of the exterior air circulated through them and for finding the best position for new ones. In order to create the geospatial maps (Figure 1), the Esri ArcGIS 9.3 platform was used to introduce geospatial coordinates obtained by identifying latitude and longitude data on site in each of the 51 subway stations.
The indoor air monitoring activity in the Bucharest subway network was simultaneously deployed in two directions throughout the year 2015, namely: microclimate - monitoring the temperature and relative humidity of indoor air that define thermal comfort and air chemistry monitoring the concentrations of: carbon monoxide and carbon dioxide and particulate matter.

The air quality monitoring network comprises: 130 automatic monitoring devices Testo $174 \mathrm{H}$, three mobile devices for collecting particulate matter and two mobile gas collecting devices (oxygen, carbon monoxide and carbon dioxide).

The automatic Testo 174H equipment has a memory capacity of up to 16.000 measurements of temperature and humidity. The measuring range is between $-20^{\circ} \mathrm{C}$ and $+70{ }^{\circ} \mathrm{C}$ for temperature and between 0 and $100 \% \mathrm{rH}$ for relative humidity. Devices are located in public and technical spaces at a height of 2 meters above the ground in lattice boxes specially designed for this purpose.

The mobile devices were used for manual measurements of particulate matter and gases (oxygen, carbon monoxide and carbon dioxide).

In order to determine the carbon monoxide and carbon dioxide concentration, samples were collected using a container attached to an absorption pump positioned at a height of 1.5 meters from the ground level. The collected sample was analyzed in the microclimate laboratory using the INFRALYT 4 device in order to determine the concentration of carbon monoxide and carbon dioxide.

To determine total particulate matter concentration paper filters were used after an absorption pump positioned at a height of 1.5 meters from the ground level. After $30 \mathrm{~min}$ the paper filters were extracted and analyzed in the laboratory.

The sample collection and analysis diagram is presented in Figure 2.

From a functional point of view, the actual monitoring system consists of three stages: supervision, evaluation of the real status and control (Figure 3).

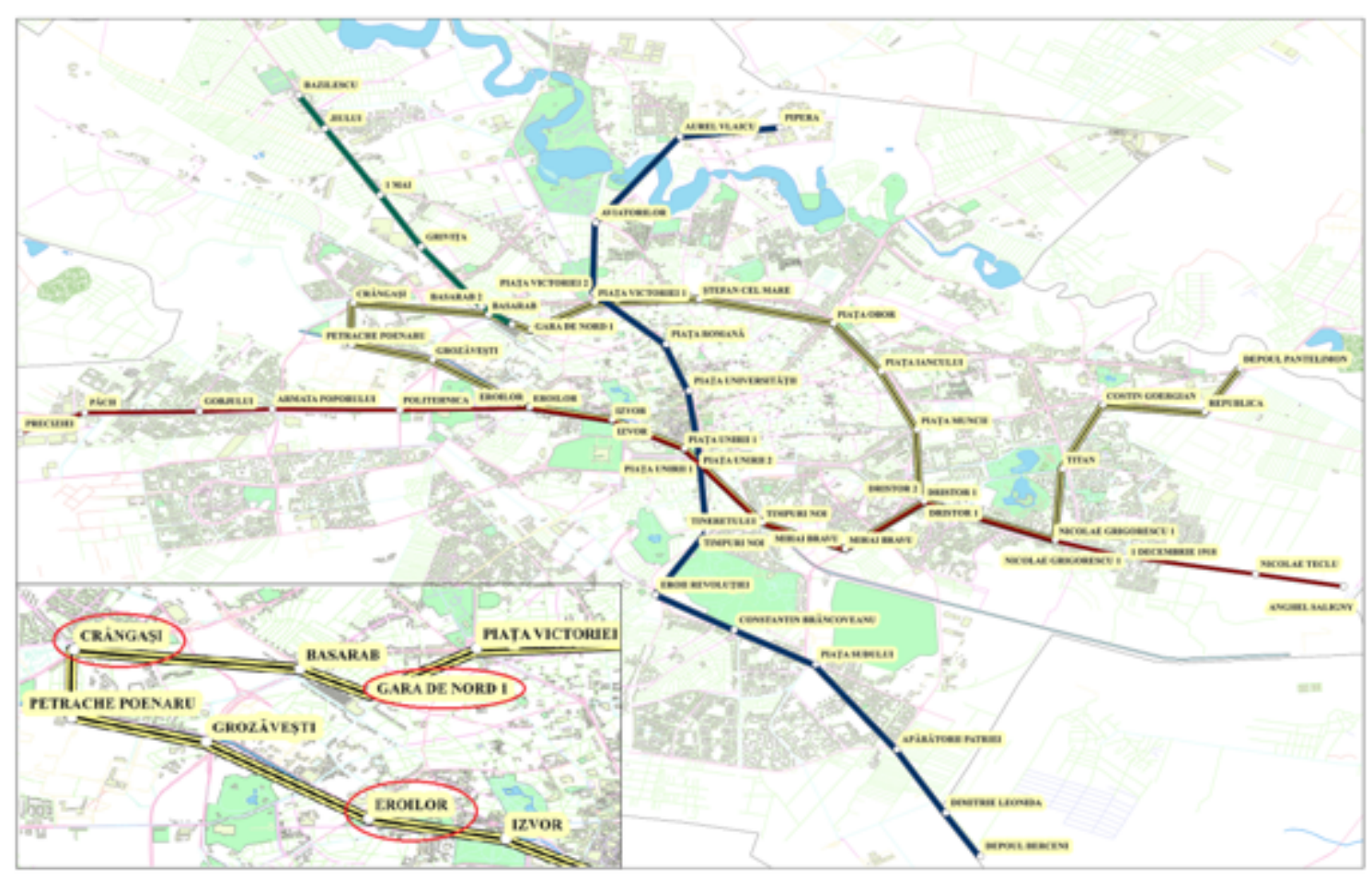

Fig. 1. Bucharest Subway GIS Map 


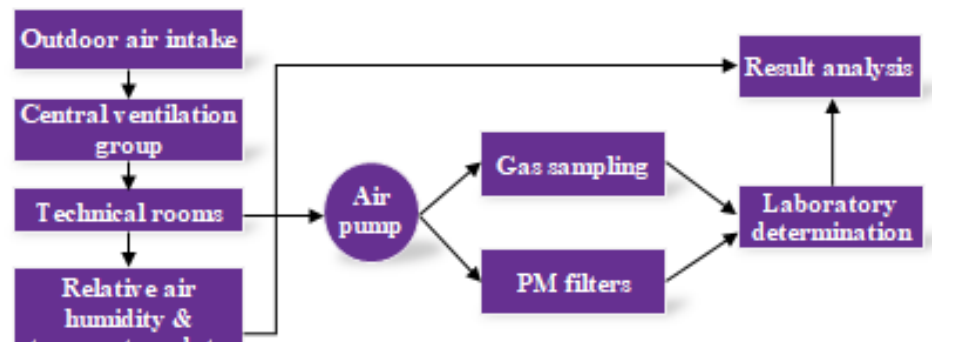

Fig. 2. Sample collection and analysis diagram

humidity \&

temperature data

acquisition

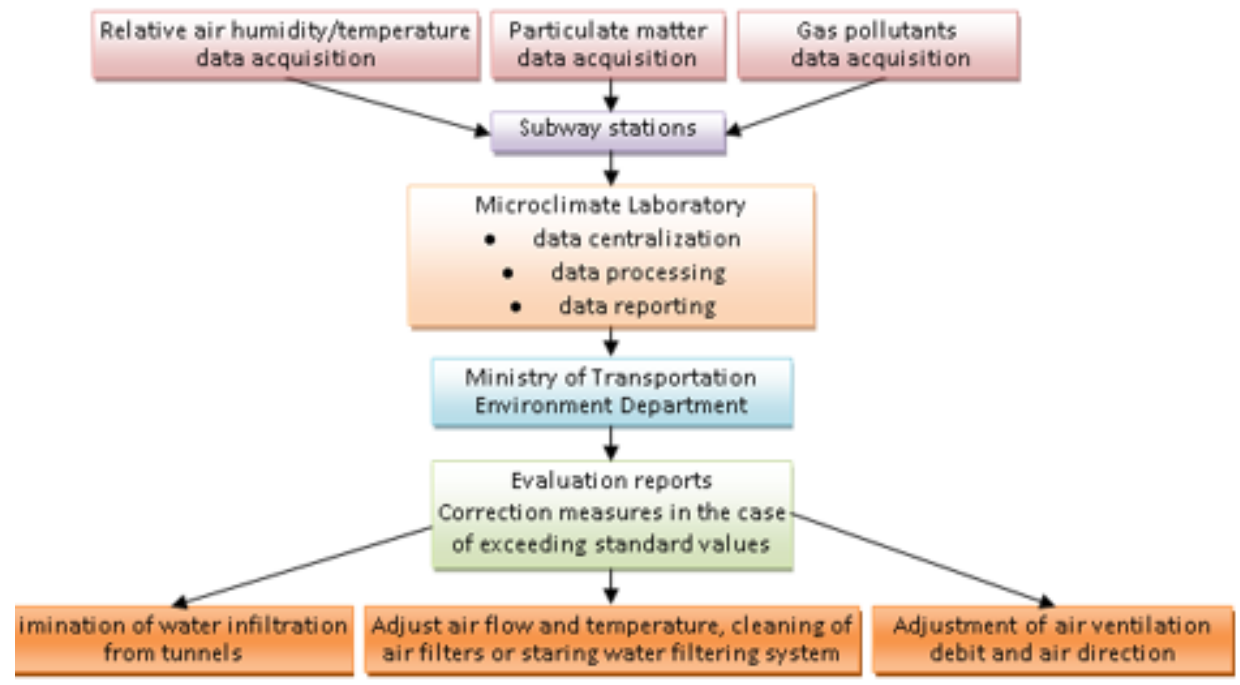

Fig. 3. Metrorex monitoring and control system architecture

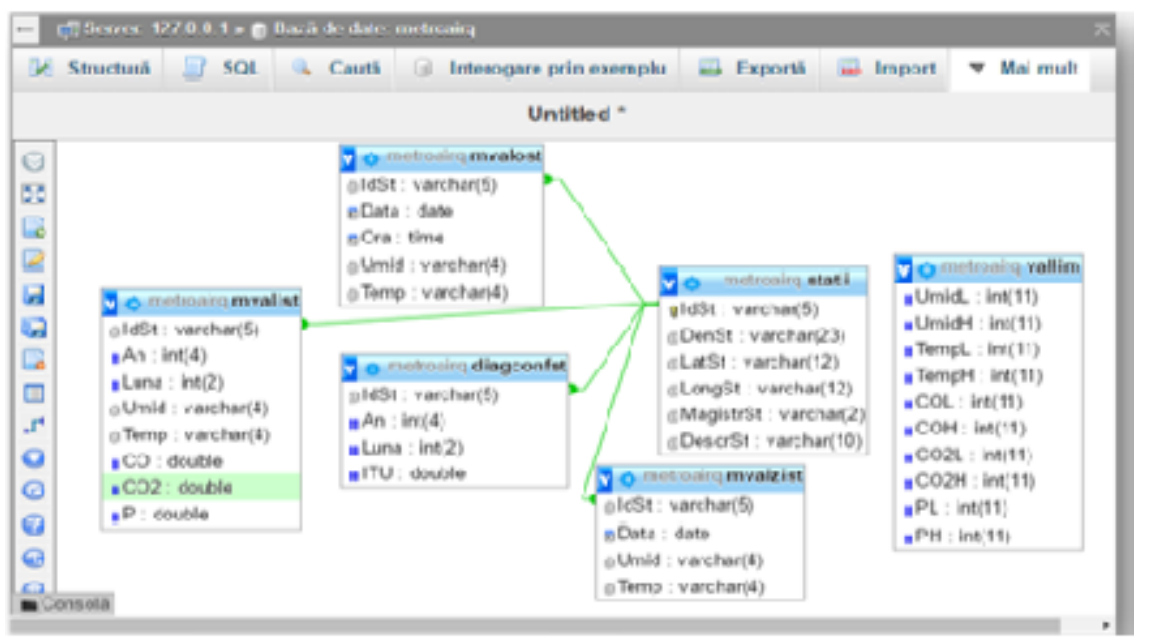

Fig. 4. Metroairq Database structure

All acquired data were stored in a MySQL database for a faster data reporting and processing. The database structure is presented in figure 4.

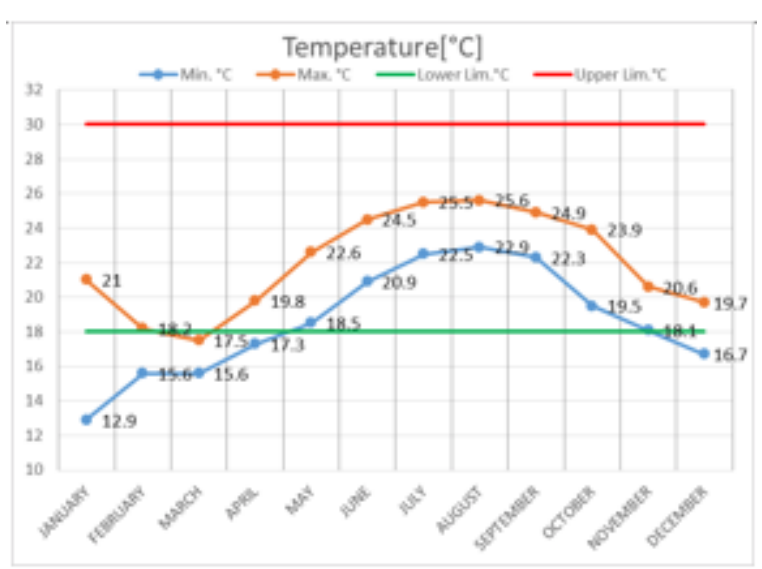

Fig. 5. Minimums and maximums of monthly temperatures at Crangasi station - 2015

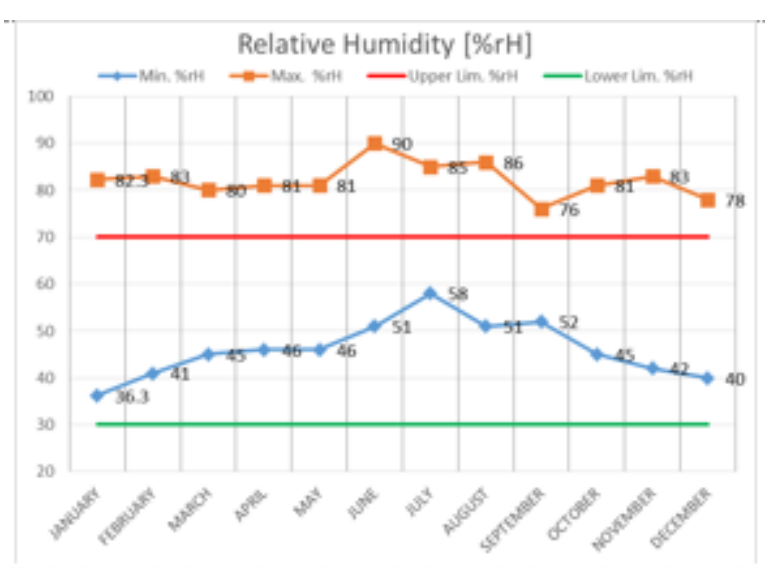

Fig. 6. Minimums and maximums of monthly relative humidity at Crangasi station - 2015 


\section{Results and discussions}

The data acquired from the sensors was statistically treated in order to highlight the minimum, the average and the maximum monthly values. The statistical data for all three stations are presented in figures 5-22.

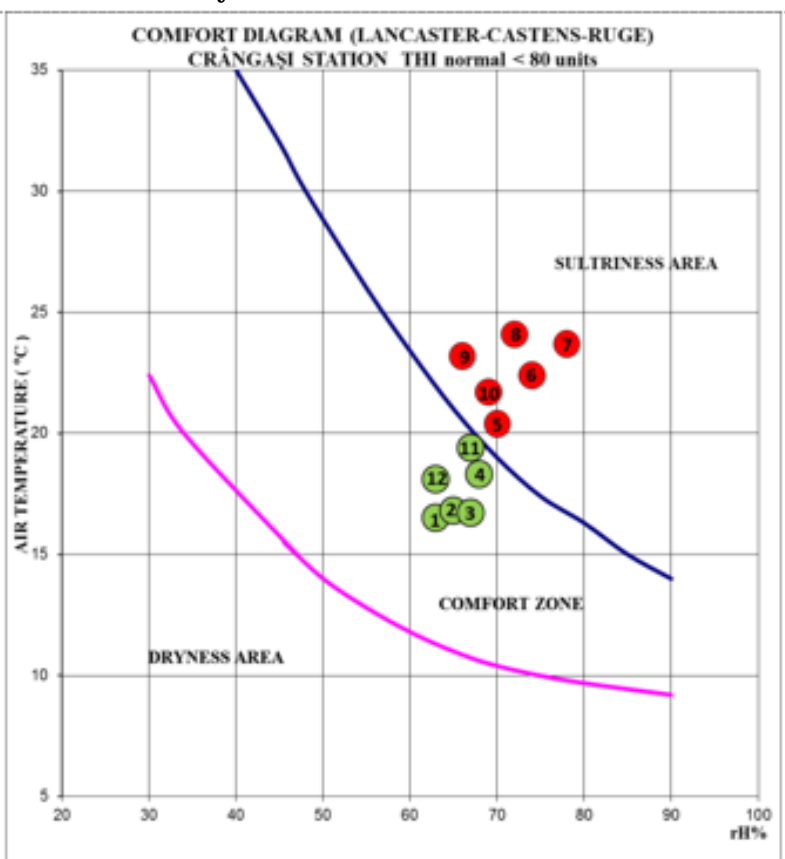

Fig. 7. Comfort diagram Crangasi station 2015

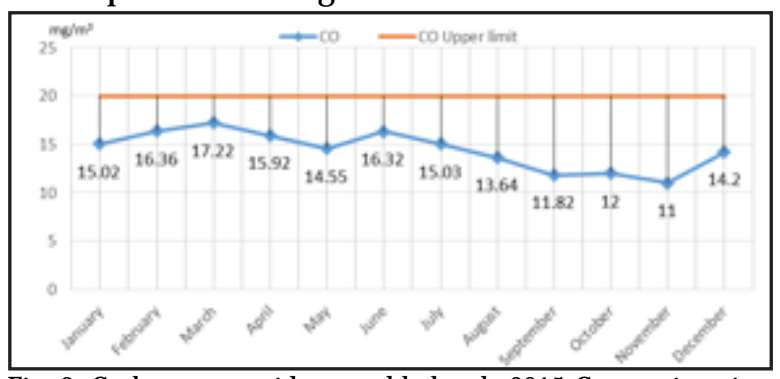

Fig. 8. Carbon monoxide monthly levels 2015 Crangasi station

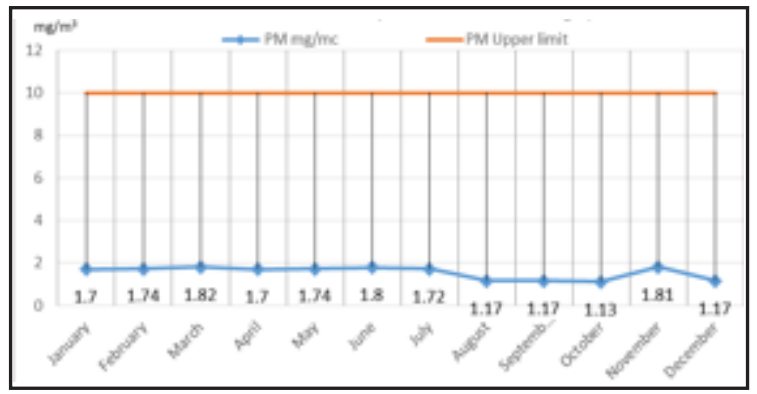

Fig. 9. Particulate matter monthly levels 2015 Crangasi station
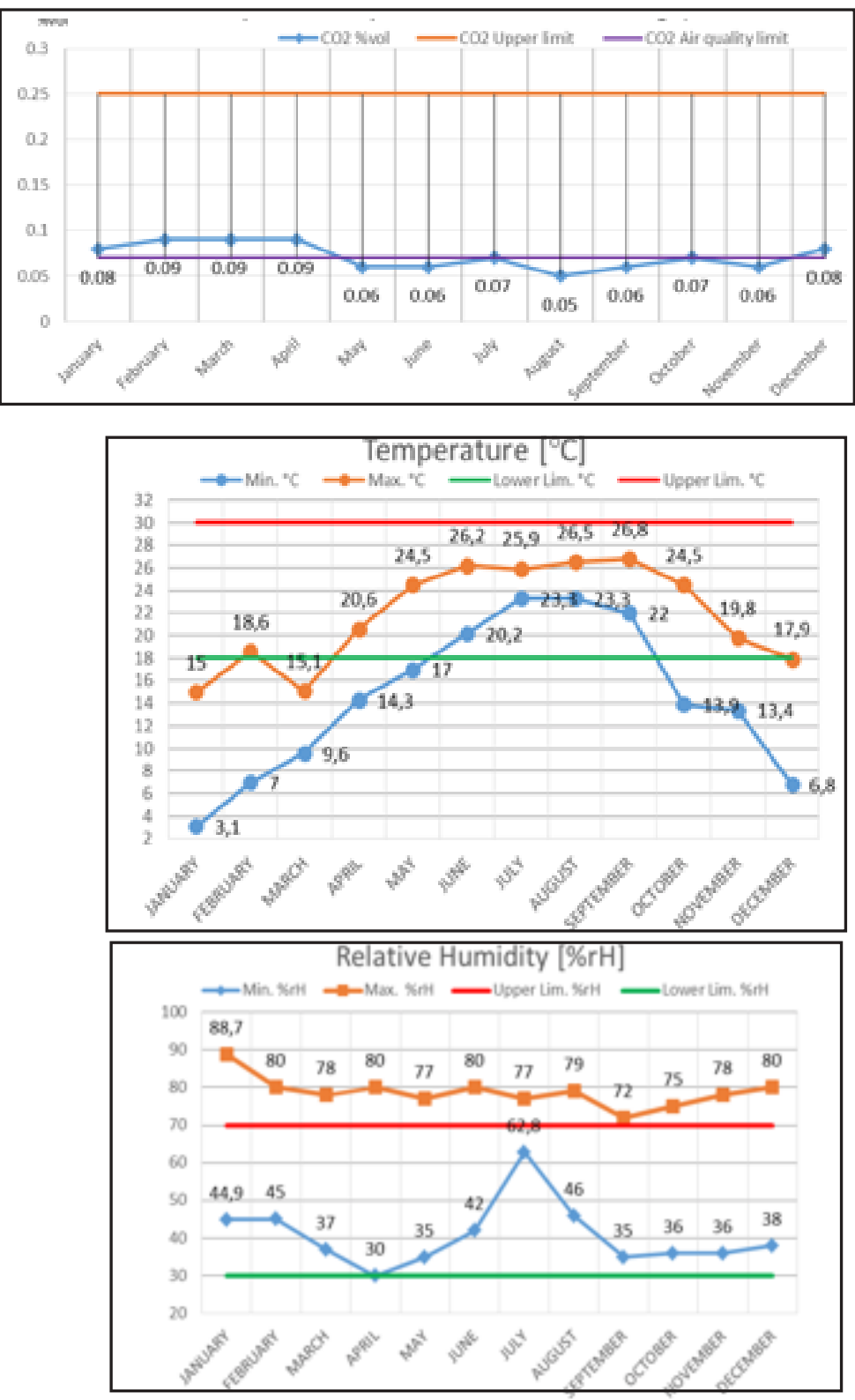

Fig. 10. Carbon dioxide monthly volume levels 2015

Fig. 11. Minimums and maximums of monthly temperatures at Gara de Nord station - 2015

Fig. 12. Minimums and maximums of monthly relative humidity at Gara de Nord station - 2015 


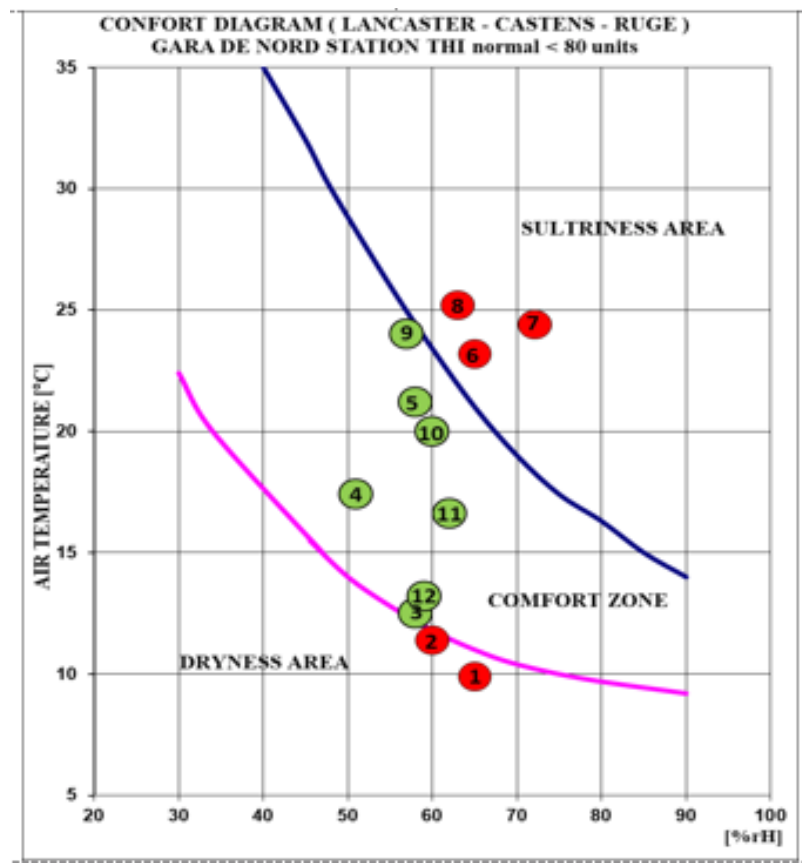

Fig. 13. Comfort diagram Gara de Nord station 2015

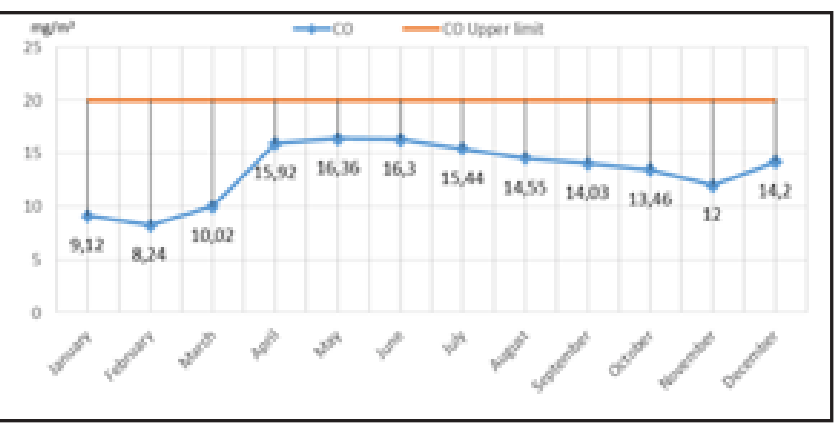

Fig. 14. Carbon monoxide monthly levels 2015 Gara de Nord station

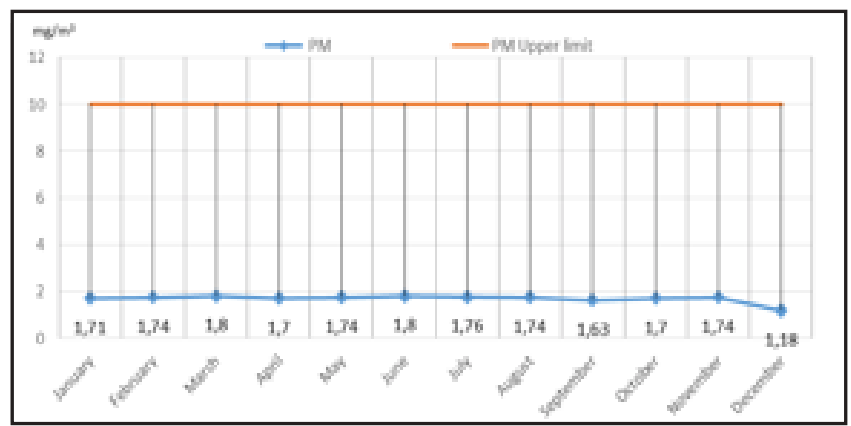

Fig. 15. Particulate matter monthly levels 2015 Gara de Nord station

In the appreciation of the thermal comfort in the subway, the Lancaster - Carstens diagram was used (Figure 7). The THI (temperature-humidity index) required for the Lancaster - Carstens diagram was calculated using the equation below:

$$
\begin{aligned}
& \text { THI }=0.8 * \text { avg. } T+0.01 * \text { avg. } r H * \\
& *(0.99 * \text { avg. } T-14.3)+46.3,
\end{aligned}
$$

where: avg. T and avg. $\mathrm{rH}$ are the average values of temperature and relative humidity, respectively.

In all three monitored stations there were deviations of the $\mathrm{THI}$ values relative to the limits as follows:

-in Crangasi station in J anuary, February, March, April, November and December the index fits into the comfort zone and in May, J une, July, August, September and October

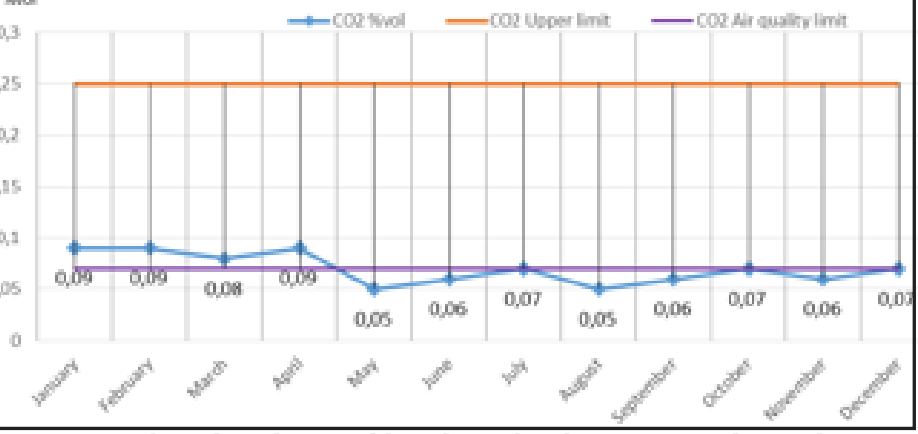

Fig. 16. Carbon dioxide monthly volume levels 2015 Gara de Nord station

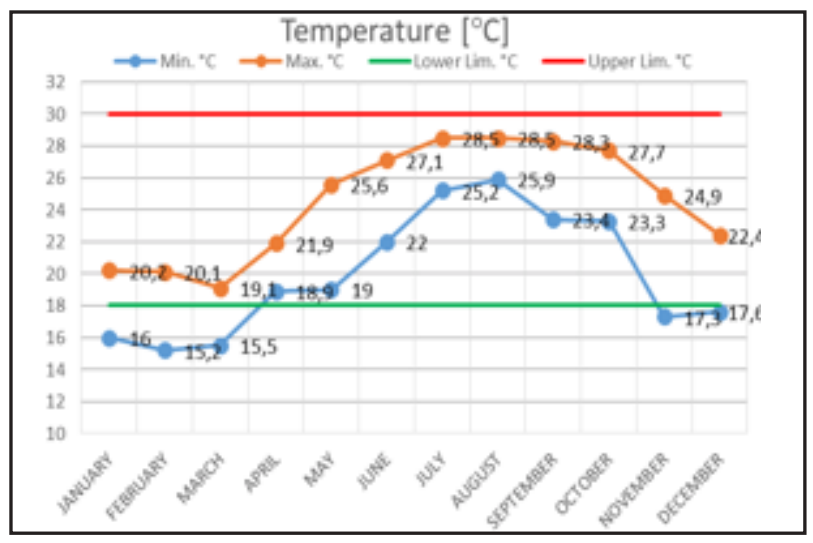

Fig. 17. Minimums and maximums of monthly temperatures at Eroilor station - 2015

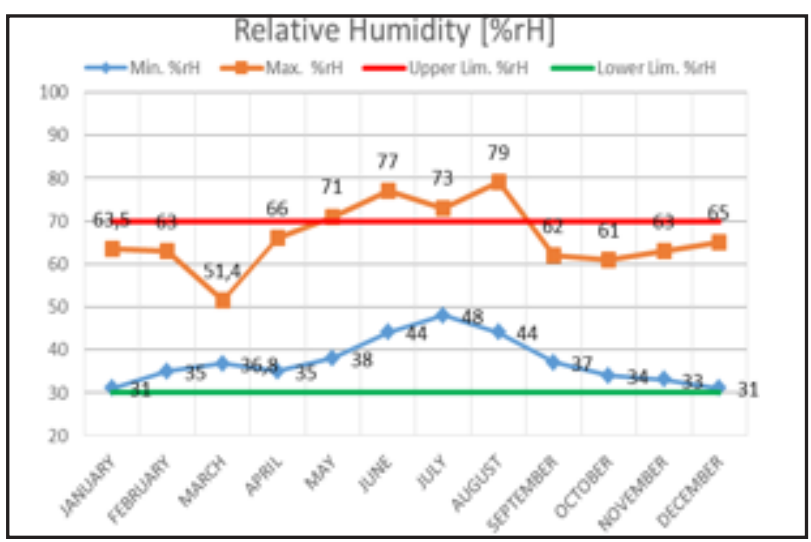

Fig. 18. Minimums and maximums of monthly relative humidity at Eroilor station - 2015

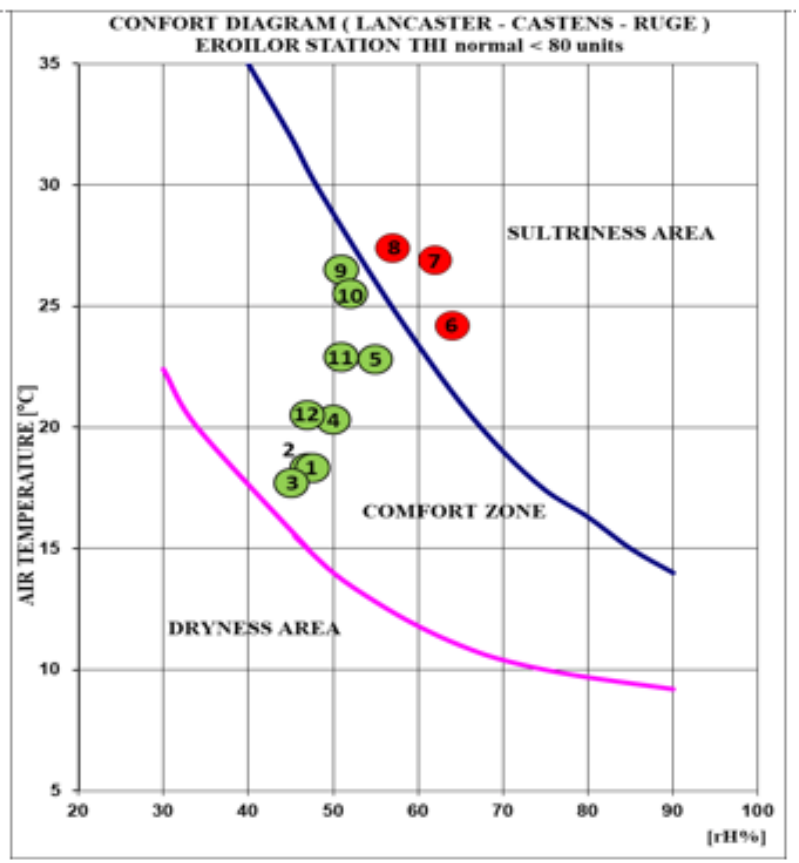

Fig. 19. Comfort diagram Eroilor station 2015 


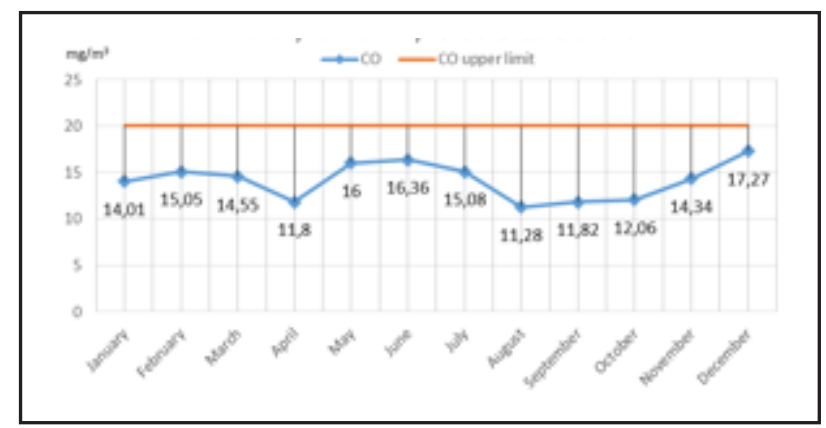

Fig. 20. Carbon monoxide monthly levels 2015 Eroilor station

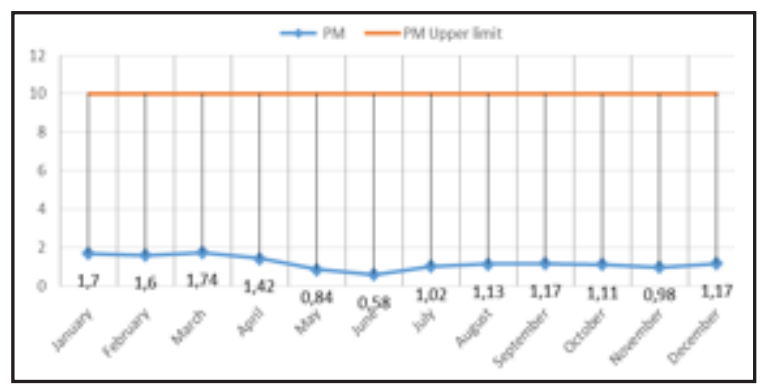

Fig. 21. Particulate matter monthly levels 2015 Eroilor station

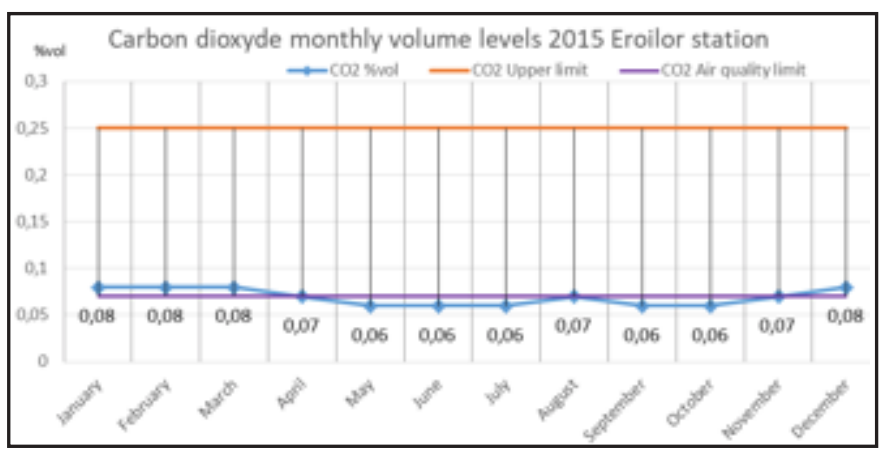

Fig. 22. Carbon dioxide monthly volume levels 2015 Eroilor station

the index leave the comfort zone and lie in the sultriness area;

-in Gara de Nord station in March, April, May, September, October, November and December the index fits into the comfort zone, in June, July, August the index leave the comfort zone and lie in the sultriness area and in January, February the index lie in the dryness area;

-in Eroilor station in J anuary, February, March, April, May, September, October, November and December the index fits into the comfort zone and in J une, July, and August the index leave the comfort zone and lie in the sultriness area.

Even if there were exceedances of one or both of the two parameters (interior temperature and relative humidity), they were short-lived and caused by extreme conditions (exterior temperatures above $35^{\circ} \mathrm{C}$ or below $15^{\circ} \mathrm{C}$ and external relative air humidity above $90 \% \mathrm{rH}$ ).

The carbon monoxide value in subway air for the case study stations ranges between 8.24 and $17.27 \mathrm{mg} / \mathrm{m}^{3}$ but never exceeded the maximum permissible limit.

The carbon dioxide value in the subway air varies between $0.05 \%$ vol. and $0.09 \%$ vol. Considering that values ranging from 0.07 to $0.1 \%$ vol. of carbon dioxide indicate the appearance of air vices, it can be concluded that frequently the air in the technical spaces of the metro is vitiated but there have been no exceedances of the admissible maximum limits of $0.25 \%$ vol.

The level of oxygen in the indoor air in the subway has never dropped below $19 \%$ vol. The phenomenon indicated by most underground workers, namely lack of air or lack of oxygen, is caused not by decreases in oxygen concentration, butby overcoming the air vitiation threshold ( $>0.07 \%$ by volume of $\mathrm{CO}_{2}$ ), combined with temperature and humidity variations, artificial illumination and continuous noise caused by mechanical ventilation.

The particulate matter concentration values in subway air for case study stations varies between 0.58 and 1.82 $\mathrm{mg} / \mathrm{m}^{3}$, but has never exceeded the maximum permissible limit of $10 \mathrm{mg} / \mathrm{m}^{3}$ of air.

\section{Conclusions}

Creating and implementing an integrated system for monitoring and controlling installations to ensure microclimate and air chemistry in the subway can improve the quality of indoor air, can make significant power savings and provide an immediate and punctual response. Also, ventilation systems will no longer work on a permanent basis.

It is necessary to implement a database management system for coherent storage and fast reporting of monitoring results.

The flow of current information is ineffective because it is dependent on outside weather conditions for thermal comfort and the response to what the sensors record must be rapid so that there is no gap between receiving the information and making a decision.

The current data collection and interpretation system for particulate matter needs to be modernized by acquiring automatic network-connected stations that can provide real-time data to decision-makers within the environmental department.

For a better quality of air flow vehiculated through the external sockets, it is necessary to lift all ground-level inlet sockets, as they existin many of the stations, up to 2 meters from the ground and surrounding these air intakes with vegetation curtains.

Acnowledgements: Support from S.C. Metrorex S.A. - The Metrorex Microclimate Laboratory - Union Square Dispatcher.

\section{References}

1. MARTINS, V., MORENO, T., MINGUILLON, M.C., AMATO, F., MIGUEL, E., CAPDEVILA, M., QUERO, X., Exposure to airborne particulate matter in the subway system, Science of The Total Environment, 511, 2015, p. 711-722, DOI: 10.1016/j.scitotenv.2014.12.013

2. XU, B., HAO, J., Air quality inside subway metro indoor environment worldwide: A review, Environment international, 107, p.33-46, 2017, DOI: 10.1016/j.envint. 2017.06.016

3. MARTINS, V., MIGUEL, E., Improving air quality in subway systems: An overview, Environmental Pollution, 239, 2018, p. 829-831, DOI: 10.1016/j.envpol. 2018.01.077

4. MORENO, T., et al., Urban air quality comparison for bus, tram, subway and pedestrian commutes in Barcelona, Environmental Research, 142, 2015, p. 495-510, DOI: 10.1016/j.envres. 2015.07.022

5. MORENO, T., MARTINS, V., RECHE, C., MINGUILLON, M. C., MIGUEL, E., QUERO, X., Chapter 13 - Air Quality in Subway Systems, in book: Non-Exhaust Emissions. An Urban Air Quality Problem for Public Health; Impact and Mitigation Measures, Academic Press, 2018, p. 289-321, DOI: 10.1016/B978-0-12-811770-5.00013-3

6. MARTINS, V., et al., Factors controlling air quality in different European subway systems, Environmental Research, 146, 2016, p.3546,DOI: 10.1016/j.envres. 2015.12.2007

7. THORNES, J., Air quality in enclosed railway stations, Proceedings of the Institution of Civil Engineers - Transport, 170, 2017, p. 99-107, DOI: 10.1680/jtran. 15.00094

8. INVERNIZZI, G., RUPRECHT, A., BETTONCELLI, G., SASCO A., Air Quality in Subway Platforms and Carriages of Six Major Cities, Epidemiology, 19, no. 6, 2008, p.144, DOI: 10.1097/01.ede. $0000339951.10181 .2 \mathrm{a}$ 
9. *** METROREX S.A., Raport de activitate pe anul 2017 al METROREX S.A., 2017, http://www.metrorex.ro/Resurse/RaportActivitate/ Raport\%20de\%20activitate-2017-RO.pdf

10. PRUSS-USTUN, A., CORVALAN, C., Preventing Disease Through Healthy Environments - Towards an estimate of the environmental burden of disease, World Health Organization, ISBN 9241593822 2006, p.18-30

11. VASILE, V., DIMA, A., ION, M., Monitoring of the Inorganic Pollutants in Built Indoor Environment, Rev. Chim. (Bucharest), 68, no. 1, 2017, p. $85-89$

12. BUCUR, E., DANET, A.F., LEHR, C.B, LEHR, E., VASILE, A., Indoor Air Quality Assessment in the Romanian National Aviation Museum, Rev. Chim. (Bucharest), 67 no 8, 2016, p. 1421-1426

13. STRANGER, M., POTGIETER-VERMAAK, S.S., VAN GRIEKEN, R., Environ Int, 33, 2007, p. 789-797

14. BUCUR, E., VASILE, A., PASCU, L.F., LEHR, C.B., VASILE, G.G., Environmental Impact Assessment Regarding Indoor Air Quality Using Statistical Methods, Rev. Chim. (Bucharest), 69, no.11, 2018, p.41254128
15. LEONACHESCU, N., UDRI'TE, G., COSTEA, A., DIACONESCU, C, Aspecte privind microclima metroului bucurestean, Revista transporturilor si telecomunicatiilor, nr. 10, 1988, p. 166

16. *** ANSI/ASHRAE Standard 55-2013, Thermal Environmental Conditions for Human Occupancy, 2013

17. GABOVICl, R.D., Igiena: Manual pentru studentii Inst. de medicina, Bucuresti, Chapter 4, 2009, p.31-32, ISBN 5-372-00949-7

18. *** European Environmental Agency, Joint EEA-J RC report No 5/ 2013, Environment and human health Report, ISBN 978-92-9213-392-4, ISSN 1725-9177

19. *** ASHRAE Standard 62-2001, Ventilation for Acceptable Indoor Air Quality, 2001

20. *** World Health Organization, WHO guidelines for indoor air quality: selected pollutants, 2010, p. 55-86, ISBN 9789289002134

Manuscript received: 4.10 .2018 